\title{
船體撓振動の固有振動數を求めろ簡易計算法
}

\author{
正員 工學士 吉 識 雅 夫*
}

\author{
I 緒言
}

船體に起る墸種の振動の內，2節の上下撓振動はその固有振動數が主機包轉數に近く，萬一主機の不本衡力と 共振を起したとするとそれを除去することは非常な困難を伴うのが普通である。從つて艦船設計の初期に於て船 體固有振動數を知り，共振を避ける樣にすることは艦船計畫上重要な一要素である。

この樣な理由により船僼撓振動の固有振動數を算定する方法は 1894 年の O.Schlick11以來多くの著者により

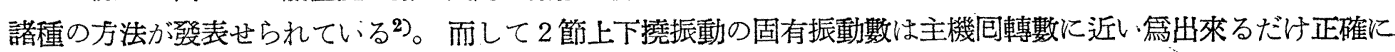
求める必要がある。その䨋には固有振動數に關係のある各種要素を詳細に取入れて算定すればそれだけ正確を期 し得る。併し斯樣にすれば手數は面倒になると共に,設計初期には所要の資料が得られず,資料の揃 と譬え共振を起すことが明かになつてもそれを避ける䉆には根本的の設計變更を要しその實行は困難となる。故 に簡單で且設計初期に得られる資料の久で出來る限り正確な值を與える方法が望まれる次第である。本論文は以 上の樣な要望に適い，設計初期に得られる資料のみを用いて出來るだけ簡單に振動數を推定する方法の一試驗案 に就いて述べんとするるのである。何本法を利用すれば商船に於ける載貨物の變動, 軍艦の砲塔位置の變動等の, 如き重量物の大きさ並びに載荷位置の變動に上る振動數の變化をる求めることが出來る。以下の適用例の內A船 の Tobin 法による計算は東京帝國大學第一工學部船舶工學科學生の卒業論交に扱われた資料によるるのであり， $C$ 船及び $D$ 船の實測值は海軍技術研究所に於て數年前に行われた實驗結果によるものである。

\section{II 船體撓振動の固有振動數の簡易計算法}

\section{1）假想枉狀船の設定}

撓振動の固有振動數は船醴の重量並びにその分布狀態, 船の長さ, 船䁗横截面の斷面二次モーメント並びにそ の分布, 船體振動につれて共に動く周圍の水の重量並びにその分布等に大なる關係を有することは既に知られて いる通りである。これ等の要素の內で, 斷面二光モーメントの分布曲線は, 梯形文は抛物線的に分布すると考兄 られている船殼及蟻裝重量の分布曲線と相似た曲線をなしている。從つてこの兩者の關係に注目すると, 振動時 に荷重となるべき船㲄及䑶裝重量の小なる前後部に於ては, 曲げに對する復原力を與える斷面二决モーメントる 小であり, 且この兩者の分布が略々等しい,ものとすれば网者の影響は相殺し, その振動數は一樣な桂狀體の值に 略 く等しくなるものと見做すことが出來る。（嚴密には兩者が比例しても一樣な柱狀體の振動數には等しくない 筈である。C. E. Inglis33は重量及び斷面二次モーメントが特殊な分布をなす場合に就き振動數を計算し，一樣な 柱狀體の值と比較している。)

それで先ず中央横截面の斷面二次モーモント I，及び船款及艤裝重量を Biles 法により梯形的に分布せしめた 場合の中央部に於ける單位長さ當りの重量 $w_{m}$ を探り，嗞面二次モーメント $I_{m}$ 及び重量分布 $w_{m}$ の一樣な柱 狀船を考光, これを假想桂狀船と稱するこことし, その振動數を求める。これ等の值は設計初期に直ちに制るる のである。(何船款及艤裝重量は Thomas 法により抛物線的に分布させた方が適當と考兄られる場合はその方を 探れば良い)。夯に今考元た梯形 (又は抛物線形) 分布以外の重量はそれぞれの重量がその重心位置に集中的に存 在するすのとして, それ等の影響による補正を行うのである。但しこれ等の集中的に存在すると考穴た重量は必 ずしも正確な值を求める必要はないのであつて，概略の配置圖等より推定した值を用いて十分である。又機關及 び䑪の載貨重量等の如く相當廣範圍に分布しているものも, その重量がその重心位置に集中して存在するものと して計算を行つてよい。特に長大な艙等は細分して 2 䇢以上の集中荷重として取扱えば更に正確さを期し得る。

* 東京帝國大學（第一工學部）助呚授 


\section{2）集中荷重に對する補正法 その一}

一樣な斷面及び重量分布を有する假悡杜狀船に對する集中重量の補正は头の樣にして行う。即ち先ず，一樣な 兩端自由梁潗中荷重が唯 1 箇存在する場合の振動數を理論計算によつて求める。(附錄第一參照) 集中荷重が 數箇存在する場合には, それ等の荷重が 1 箇宛存在するるのとして各荷重に對して理論值 $N_{i}$ を求める。數䇢の 集中荷重が同時に存在する場合の振動數 $N$ は次の如くに求める。郎ち

$N_{0}=I_{m}$ 乙文び $w_{m}$ の一樣な假想柱狀船の振動數

$N_{i}=$ 柱狀船に集中荷重 $W_{i}$ が唯 1 箇存在する場合の振動數, $(i=1,2, \cdots k, k$ は集中荷重の總數

$n_{i}=$ 柱狀船は質量はなく, 曲げ岡性のみがあるるのと假定し, それに $W_{i} 1$ 籄が作用する場合の振動數 とすると，Dükerley出の考光を適用して

$$
\frac{1}{N_{i}{ }^{2}}=\frac{1}{N_{0}^{2}}+\frac{1}{n_{i}{ }^{2}}
$$

$W_{1}, W_{2}, \cdots W_{k}$ が同時に存在する場合の振動數 $N$ は

$$
\begin{gathered}
\frac{1}{N^{2}}=\frac{1}{N_{0}{ }^{2}}+\sum_{i=1}^{k} \frac{1}{n_{i}{ }^{2}} \quad(i=1,2, \cdots, k) \\
=\sum_{i=1}^{k} \frac{1}{N_{i}{ }^{2}}-(k-1) \frac{1}{N_{0}{ }^{2}}
\end{gathered}
$$

而して $N_{0}$ は头式で與兄られる。

$$
N_{0}=\frac{(m l)_{0}^{2}}{2 \pi l^{2}} \sqrt{\frac{E I_{m} g}{w_{m}}}
$$

但し $(m l)_{0}$ は

$$
\cos m l \cosh m l-1=0
$$

の根で, 兩端自由 2 節振動の場合は 4.730 である。

倘

$$
\begin{aligned}
l & =\text { 船の長さ } \\
E & =\text { 船體構造の彈性俰數 } \\
g & =\text { 重力の加速度 } \\
I_{m} & =\text { 假想桂狀船の斷面二次モーメント } \\
w_{m} & =\text { 同上の單位長さ當りの重量 }
\end{aligned}
$$

である。又

$$
N_{i}=\frac{(m l)_{i}^{2}}{2 \pi l^{2}} \sqrt{\frac{E I_{m} g}{w_{m}}}
$$

で $(m l)_{i}$ は $W_{i}$ の大きさ及びその作用位置の函數で第 1 圖及第 2 圖に示す值となる。從つて上式により數箇の 集中荷重の存在する場合の振動數か求められることになる。上式は次の樣書き改めて使用しても良い。

\section{3）集中荷重に對する補正法 そのニ}

$$
N=N_{0}\left[\sum_{i=1}^{k} \frac{(m l)_{0}{ }^{4}}{(m l)_{i}{ }^{4}}-(k-1)\right]^{-\frac{1}{2}}
$$

一樣な假想桂狀船の斷面二次モーメントを $I_{m}$, 單位長さの重量を $w_{m}$ とし， $x_{m}$ の點に集中荷重 $W$ が存在 するものとする。此の振動系の運動エネルギを $T$ ，ポテンシャル・エネルギを $V$ とすると，それ等はそれぞれ 头の如く表わされる。

$$
\begin{aligned}
& T=\frac{1}{2} \frac{w_{m}}{g} \int_{0}^{l}\left(\frac{\partial y}{\partial t}\right)^{2} d x+\frac{1}{2} \sum_{i=1}^{k} \frac{W_{i}}{g}\left(\frac{\partial y_{i}}{\partial t}\right)^{2} \\
& V=\frac{1}{2} E I_{m} \int_{0}^{l}\left(\frac{\partial^{2} y}{\partial x^{2}}\right)^{2} d x .
\end{aligned}
$$

但し $y$ は振動の撓及を示し， $y_{i}$ 、はその $x_{i}$ に於忛る值である。

振動の圓振動數を $p$ とすると

$$
y=u(x) \cos (p t+\varepsilon)
$$

と書くことが出來る。故にエネルギ法則を適用すれば, 


$$
p^{2}=\frac{E I_{m} \int_{0}^{l}\left(\frac{d^{2} u}{d x^{2}}\right)^{2} d x}{\frac{w_{m}}{g} \int_{0}^{l} u^{2} d x+\sum_{i} \frac{W_{i}}{g} u_{i}{ }^{2}} .
$$

此處で $u$ に就いて近似的の取扱いをして一樣な兩端自由梁のノルマル函數を用いることとする。邲ち

$$
\begin{aligned}
u= & (\cos m l-\cosh m l)(\cos m x+\cosh m x) \\
& +(\sin m l+\sinh m l)(\sin m x+\sinh m x)
\end{aligned}
$$

但し

$$
m^{4}=\frac{w_{m}}{g E I_{m}} p_{0}^{2}, \quad \frac{p_{0}}{2 \pi}=N^{0} \text {. }
$$

從つて

$$
\begin{aligned}
& \int_{0}^{l} u^{2} d x=\frac{l}{4} u_{0}^{2} \\
& \int_{0}^{l}\left(\frac{d^{2} u}{d x^{2}}\right)^{2} d x=\frac{l}{4} m^{4} u_{0}^{4} .
\end{aligned}
$$

但し

$$
u_{0}=2(\cos m l-\cosh m l)
$$

故に假想桂狀船の振動週期を $T_{0} . W_{1}, W_{2}, \cdots W_{k}$ の存在する場合の週期を $T$ とすれば，

$$
T_{\mathrm{o}}=\frac{2 \pi}{p_{0}}, \quad T=\frac{2 \pi}{p}
$$

であるから，

$$
\begin{aligned}
T^{2} & =\frac{4 \pi^{2} w_{m}}{E I_{m} g} \frac{\int_{0}^{l} u^{2} d x}{\int_{0}^{l}\left(\frac{d^{2} u}{d x^{2}}\right)^{2} d x}+\frac{4 \pi^{2}}{E I_{m} g} \frac{\sum_{i} W_{i} u_{i}{ }^{2} .}{\int_{0}^{l}\left(\frac{d^{2} u}{d x^{2}}\right)^{2} d x} \\
& =T_{0}{ }^{2}\left[1+4 \sum_{i=1}^{k} r_{i}\left(\frac{u_{i}}{u_{0}}\right)^{2}\right]
\end{aligned}
$$

但乙

$$
r_{i}=W_{i} / w_{m} l \text { (集中荷重と柱狀船の重量比) }
$$

故に

$$
\boldsymbol{T}=\boldsymbol{T}_{\mathrm{o}}\left[1+4 \sum_{i=1}^{k} r_{i}\left(\frac{u_{i}}{u_{0}}\right)^{2}\right]^{\frac{1}{2}}
$$

振動數 $N$ は

$$
N=N_{0}\left[1+4 \sum_{i=1}^{k} r_{i}\left(\frac{u_{i}}{u_{0}}\right)^{2}\right]^{-\frac{1}{2}}
$$

即ち集中荷重の假想柱狀船に對する重量比 $\boldsymbol{r}$ ， と，その作用位置に於けるノルマル函數の值と船の前後端に於け る值との比 $\left(u_{i} / u_{0}\right)$ を知れば, 上式によつて任意の集中荷重が存在する場合の振動數が求められる。 $\left(u / u_{0}^{2}\right)$ の 值を第 3 圖に曲線で示す。同圖に於ては船の中央を坐標原點に探り，前後端を $0.5 l$ としてある。

\section{III 解法の適用例}

\section{1) $\mathbf{A}$ 船}

次の如き重要寸法を有する三島型貨物船に就いて，墸種の載貨狀態に對して本法を應用して振動數を計算し， Tobin5)法による計算値と比較した。

$$
\begin{array}{cccccc}
L_{p p} & 400 \prime-0 \prime \prime & B & 53 \prime-0 \prime \prime & D & 32 \prime-0 \prime \prime \\
\text { 满載吃水 } & 25 \prime-7.8 \prime \prime & & & &
\end{array}
$$

本船の斷面二次モーメントは計算の結果第 4 圖の○印の值を得た。船樓端に於ける非有效性等を考慮し，同圖 の筫線の如き分布と假定した。重量分布に就いては，船殻及艟裝重量 2895.0 ton をBiles の梯形法則で分布し， 各艙その他の重量は夫々の位置に累加することとした。但し便宜上二重底內載貨重量 1048.6 ton は假想杜狀船 の重量に加光, $w_{m}=11.12$ ton $/ \mathrm{ft}$ とした。

$$
\left(w_{m}=\frac{2895.0}{400} \times 1.174+\frac{1048.6}{400}=11.12 \text { ton } / \mathrm{ft}\right)
$$

佾斷面二次モーメントは $I_{m}=3322 \mathrm{ft}^{4}$ である。

各部分の重量其他は第 1 表浜す。 
本船に對する假想杜狀船の振動數 $N_{0}$-は光の如くである。

$$
N_{0}=\frac{4.730^{2} \times 60}{2 \pi \times 400^{2}} \sqrt{\frac{13500 \times 3322 \times 144}{11.12}}=183^{1} / \mathrm{min}
$$

头の五種の狀態に對して計算を行う。（第 5 圖參照）
A 狀態; 燃料槽, 石炭庫及豫備給水槽滿載

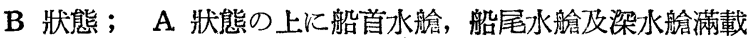
C 狀態; A 狀態の上に第一番艙及甲板間, 第三番䑪及第四番甲板間に貨物積載
D 狀態： A 狀態の上に第二番艙及甲板間, 第三番甲板間及び樑水槽に貨物積載
$\mathrm{E}$ 狀態; 满載狀態

以上の各狀態に對し，第一法及第二法を適用して計算した值及び Tobin 法によるものを比較すると第 2 表の通り である。

本表中（）內の數字は艙を 2 等分して計算した值を示す。

\section{2) $\mathbf{B}$ 船}

1932 年に Schadlofsky6)の發表している油槽船に本法を適用して比較した。本船の要自は次の通りである。

$$
\begin{array}{llllllll}
L_{0 \alpha} & 140.65 \mathrm{~m} & L_{p p} & 134.11 \mathrm{~m} & B & 19.51 \mathrm{~m} & D & 10.744 \mathrm{~m}
\end{array}
$$

滿載排水量 $16900 \mathrm{t}$ 載貨重量 $11000 \mathrm{t}$

中央横截面の慨面二次モーメント $\left(\boldsymbol{I}_{m}\right) 36.159 \mathrm{~m}^{4}$

本船の船殼及盘裝重量は不明なりしにより重量曲線其他より $4250 \mathrm{t}$ と假定した。從つて $w_{m}$ は $35.7 \mathrm{t} / \mathrm{m}$ と なる。故に假想桂狀船の振動數 $N_{\mathrm{o}}$ は

$$
N_{0}=\frac{4.730^{2} \times 60}{2 \pi \times 140.65^{2}} \sqrt{\frac{2.1 \times 10^{8} \times 36.159 \times 9.8 \times 10^{4}}{35.7 \times 10^{3}}}=156^{1} / \mathrm{min}
$$

第 6 圖は原論文より轉載した重量及斷面二光モーメント曲線で，それより集中荷重を第 3 表の如く計算した。 從つて第一法及び第二法による計算值は夫及每分 105 及び 95.6 となる。一方 Schadlofsky の圖式積分によ る計算值は每分 117.9 であり, 船體と共に動く水の影響その他の影響を加算した值は 81.5 で, 實㵋值は 81 で ある。

\section{3) $\mathbf{C}$ 船}

長さ $204 \mathrm{~m}, I_{m} 59.6 \mathrm{~m}^{4}$ の C 船に對し, 船懞及裁裝重量を第 7 圖點線の如くに假定し, その點線以上の重量

\begin{tabular}{|c|c|}
\hline 第一法 & $77.5^{1} / \mathrm{min}$ \\
\hline 第二法 & 72.2 \\
\hline 實測値 & 61 \\
\hline Pavlenko 法 $\tau$ ) & 71 \\
\hline Bailey 法8) & 84 \\
\hline
\end{tabular}
は集中荷重として取扱つて計算を行つた（第 4 表）。郎ち $w_{m}$ を $26.35 \times 10^{3} \mathrm{~kg} / \mathrm{m}$ とし，假想桂狀船の振動數 $N_{0}$ を求めると,

$$
N_{0}=\frac{4.730^{2} \times 60}{2 \pi \times 204^{2}} \sqrt{\frac{2.1 \times 10^{10} \times 59.6 \times 9.8}{26.35 \times 10^{3}}}=111^{1} / \mathrm{min}
$$

\section{4) D 船模型 (銅製)}

模型船の寸法等は長さ $21.45 \mathrm{ft}, I_{m} 0.0404 \mathrm{ft}^{4}$, 排水量 0.935 ton で, $w_{m}$ は $0.019^{1}$ ton $/ \mathrm{ft}$ と假定した。C 船同樣船款及艤裝重量不詳なりしにより，排水量の約 $37 \%, 0.343$ ton をとの重量と推定して $w_{m}$ を定めた。第 8 圖の點線がこの假想の船殼及艤裝重量の分布曲線である。その點線を超えた部分を集中荷重として扱つて計算 を行うことは C 船と同樣である。（第 5 表）

假想杜狀船の掁動數 $N_{0}$ は

$$
N_{0}=\frac{4.730^{2}}{2 \pi \times 21.45^{2}} \sqrt{\frac{13500 \times 0.0404 \times 32.2 \times 144}{0.0191}}=88.91 / \mathrm{sec}
$$

第一法 $68.9^{1} / \mathrm{sec}(57.2)$

第二法 $67.0 \quad(57.6)$

實測値空中 $49.5^{1} / \mathrm{sec}$ 水上 $40.0^{1} / \mathrm{sec}$ 


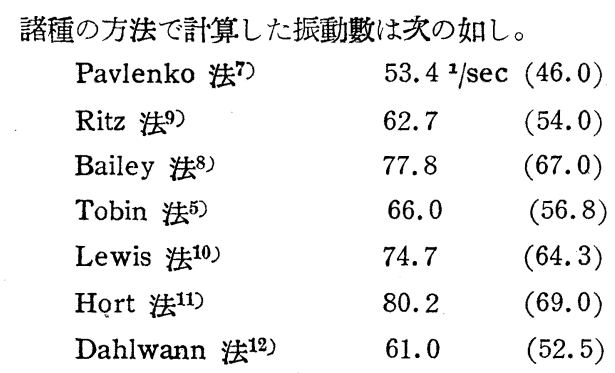

（ ）內の數字は $E=10,000$ ton/ロ” として計算した值にして, 原報告にこの數值にて計算せられ居りしにより 探錄せるものなり。

\section{IV 結 言}

以上四船への適用例に見る如く第一法第二法共に，大體同一の結果を與光る樣である。 $A$ 船の例に於て $C$, $D$ 攻 $E$ 狀態に於ては，第一法は多少大き過ぎる值を示す樣である。其他の場合は各船共略乃同一の結果になつ ていること, 並に $C, D, E$ 狀態にて子艙を分割して訫算すると振動數は減少すること等より判斷すると, 相當 廣範圍に分布する重量を 1 箇の集中荷重と見做して計算を行 5 場合には第二法の方が適當であると考兄られる。 併し $A$ 船の $A$ 狀態又は附錄の實驗例の如く集中荷重の數少く, 且それが集中して作用する場合は第一法が適 當と考兄られる。 $A$ 船以外の如く大體 10 箇程度以上の集中荷重に分けて訫算寸れば兩法とも略々同一の值とな る。合 $D$ 船の例で見る如く本法は他の諸法に比し抙色なき值を示すと共に, 簡單にして設計初期に得られる資 料のみによつて計算出來る點では斷然優れている。

以上適用例孔僅少であり，本法の使用價值の判定は更に多くの實例との此較に俟つべきであるが，相當望みを 囑し得るものと云うことが出來る。何船體振動數の算定に就いては, 剪㫁撓みの影響等墸種の影響, 就中船體と 共に動く水の附加重量の問題を解決せねば水上に於ける振動數を得ることは出來ないことは，既に多くの著者 ${ }^{13}$ によつて明かにせられている所であるが，本論文に於てはこれ等の點には觸れていない。（以上）

\section{V 文獻}

1) O. Schlick ; Further Investigations of the Vibrations of Steamers. T. I. N. A. 35 (1894) p. 350

2）實驗公式によるもの

O. Schlick；前揭

L. Gümbel ; Ebene Transversalschwingungen freier stabförmiger Körper mit variablen Querschnitt und beliebiger symmetrischer Massenverteilnng unter der Einwirkung periodischer Kräfte mit speciellen Berücksichtung des Schwingungsproblemes des Schiffbaues. Jahrb. d. Schiffb. te.chn. Ges., 2 (1901) s. 211

L. C. Burrill ; Simple Methods of Estimating Critical Frequencies. Trans. N. E. C. Inst. Eng. \& Shipb., 51 (1934-5) p. 259

F. H. Todd ; Vibration in Ships. Engg. Sept. 1938, p. 345 , 375

振動方程式を圖式に解くもの

L. Gümbel ; 前揭

横田成年；On Vibration of Steamers. 東京帝大工科大學紀要 5 (1910明 43) p. 1

Uniform bar の解を基として圆式に解くもの

T. C. Tobin; A Method of Determining the Natural Periods of Vibration of Ships. T.I. N. A., $64_{\star}(1922)$ p. 153

F. M. Lewis; Vibration and Engine Balance in Diesel Ships. Trans. Soc. N. A. \& M. E., 35 (1927) p. $259 \sim$

J. L. Taylor; Ship Vibration Periods. Trans. N. E. C. Inst. Eng. \& Shipb., $44(1927 \sim 8)$ p. 143 $\sim$,

I. w 曲線を假定して數値計算を行うもの

N. W. Akimoff; On Vibrations of Beams of Variable Cross-Section. Trans. Soc. N. A. \& M. E., 26ः(1918) p. 111 
G. E. Pavlenko ; A Method of Calculating Ship Vibrations. Engg., 121 (1926) p. 748 靜荷重による撓み曲線を基とし, 圖式に解くもの

W. Gatewood; Period of Vibration of Steam Vessels. Trans. Soc. N. A. \& M. E., 23 (1915) p. $117 \sim$

Dynamical model の實驗によるもの

A. Mallock; On the Vibrations of Ships and Engines. T. I. N. A., 36 (1895) p. 296

J. B. Henderson; The Vibrations of Ships and the Use of a Dynamical Model for Determining the Elasticity of Ships. T. I. N. A., 51 (1909) p. 29

3) C. E. Inglis; Natural Frequencies and Modes of Vibration in Beams of Non-Uniform Mass and Section. T. I. N. A., 71 (1929) p. 145

4) S. Dunkerley; On the Whirling and Vibration of Shafts. Phil. Trans. Roy. Soc. London, A. 185 (1894) Part I. p. 279

5) T. C. Tobin ; 前揭 2)

6) E. Schadlofsky; Ueber Rechnung und Messung der elastischen Eigenschwingungen von Schiffskörpern. Jahrb. Schiffb. techn. Ges., 33 (1932) s. 282 325

7) G. E. Pavlenko; 前揭 2)

8) F. Bailey ; T. I. N. A., 64 (1922) p. 162

9) W. Ritz; 例えぱ Trans. Soc. N. A. \& M. E., 26 (1918) p. 131 等

10) F. M. Lewis ; 前揭 2)

11) W. Hort; Die Differentialgleichungen des Ingenieurs. (Berlin, 1925) s. 372

12) W. Dahlmann; Festigkeit der Schiffe. (Berlin. 1925) s. 88

13）剪斷撓みの影響に就いては

H. W. Nichols ; Vibration of Ships. T. I. N. A., 66 (1924) p. 141

F. M. Lewis ; 前揭 2)

J. L. Taylor ; 前揭 2)

A. P. Cole; The Natural Periods of Vibration of ships. Inst. Eng. \& Shipb. Scotlandp. 72 (1928-9) p. 43〜

J. L. Taylor; Vibration of Ships T. I. N. A., 72 (1930) p. 162

F. H. Todd ; Ship Vibration-A Comparison of Measured with Calculated Frequencies. Trans.

N. E. Coast Inst. Eng. \& Shipb., 49 (1932 3) p. 259

E. Schadlofsky ; 前揭 6)

L. C. Burrill ; 前揭 2)

船體と共に動く水の附加重量の影響に就いては

寺田寅趇; On the Vibration of a Bar floating on a Liquid Surface.數物學會記事 1906, p. 103 橫田成年；前揭 2)

H. W. Nicholls ; 前揭

A. P. Cole ; 前揭

F. M. Lewis; The Inertia of the Water surrounding a Vibrating Ship. Trans. Soc. N. A. \& M. E., 37 (1929) p. 1

J. L. Taylor ; Some Hydrodynamical Inertia Coefficients. Phil. Mag. 9 (1930) p. 161

J. L. Taylor; 前揭

E. Schadlofky ; 前揭6)

L. C. Burrill ; 前㖞2)

\section{VI 附錄第一 集中荷重 1 箇を有する斷面一樣なる兩端 自由梁の振動數に就いて}

一樣な斷面を有する兩端自由梁に 1 䇢の集中荷重が加わつた場合の固有振動數を計算する篇，附錄第 1 圖に示 す樣な梁を想定する。 $l$ を兩端自由梁 $\mathrm{AB}$ の長さとし, $\mathrm{AB}$ の中點 $\mathrm{C}$ より距離 $z l$ の點 $\mathrm{D}$ に集中荷重（質量 M) があるるのとす。

$\mathrm{AD}$ 間及び $\mathrm{DB}$ 間の變位を夫々 $y_{1}$ 及び $y_{2}$ とし，減衰力及间轉慣性等を無視すれば，振動方程式は夫々次の 如くなる。

$\mathrm{AD}$ 間淦しては

$$
E I \frac{\partial^{4} y_{1}}{\partial x_{1}{ }^{4}}+\rho a \frac{\partial^{2} y_{1}}{\partial t^{2}}=
$$


DB 間に對しては，

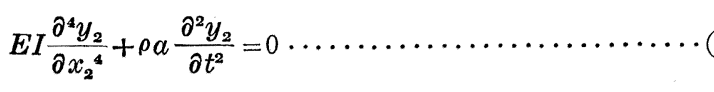

此處に $E=$ 梁の材質のヤング保数

$I=$ 梁の斷面二次モーメント

$a=$ 梁の斷面積

$\rho=$ 梁の材質の比重

撓みを次の如く假定する。

$$
\left.\begin{array}{l}
y_{1}=u_{1}(x) \sin p t \\
y_{2}=u_{2}(x) \sin p t
\end{array}\right\}
$$

（3）を（1）劝び（2）に代入して $u(x)$ に就いて解壮ば

$$
\left.\begin{array}{l}
u_{1}(x)=A_{1} \cos m x_{1}+B_{1} \sin m x_{1}+C_{1} \cosh m x_{1}+D_{1} \sinh m x_{1} \\
u_{2}(x)=A_{2} \cos m x_{2}+B_{2} \sin m x_{2}+C_{2} \cosh m x_{2}+D_{2} \sinh m x_{2}
\end{array}\right\}
$$

但し

$$
m^{4}=\frac{\rho a}{E I} p^{2}
$$

所要の境界條件は

$$
\begin{aligned}
& x_{1}=0 \text { に於 } \tau, \quad \frac{\partial^{2} y_{1}}{\partial x_{1}^{2}}=0, \frac{\partial^{3} y_{1}}{\partial x_{1}^{3}}=0 \\
& x_{1}=k l, \quad x_{2}=0 \text { に於て, } \\
& y_{1}=y_{2}, \quad \frac{\partial y_{1}}{\partial x_{1}}=\frac{\partial y_{2}}{\partial x_{2}} \\
& \left(-E I \frac{\partial^{2} y_{1}}{\partial x_{1}^{2}}\right)_{x_{1}=k l}=\left(-E I \frac{\partial^{2} y_{2}}{\partial x_{2}^{2}}\right)_{x_{2}=0} \\
& \left(-E I \frac{\partial^{3} y_{1}}{\partial x_{1}^{3}}\right)_{x_{1}=k l}+M\left(\frac{\partial^{2} y_{1}}{\partial t^{2}}\right)_{x_{1}=k l}=\left(-E I \frac{\partial^{3} y^{2}}{\partial x_{2}{ }^{3}}\right)_{x_{2}=0} \\
& x_{2}=k k^{\prime} l \text { に於て, } \frac{\partial^{2} y_{2}}{\rho x_{2}^{2}}=0, \frac{\partial^{3} y_{2}}{\partial x_{2}{ }^{3}}=0
\end{aligned}
$$

（6）の 8 箇の條件式より $A_{1}, B_{1} \cdots D_{2}$ の 8 箇の係數を消去して $m$ に就いての條件式郎ち振動數方程式を求 めると,

$$
\begin{aligned}
& 1-\cos m l \cdot \cosh m l \\
& =\frac{1}{4} r m l[\sinh m l(\cos m l+\cos 2 z m l)-\sin m l(\cosh m l+\cosh 2 z m l) \\
& +4 \sinh \frac{m l}{2} \cdot \cos \frac{m l}{2}(\cosh z m l \cdot \cos z m l-\sinh z m l \cdot \sin z m l) \\
& \left.-4 \cosh \frac{m l}{2} \cdot \sin \frac{m l}{2}(\cosh z m l \cdot \cos z m l+\sinh z m l \cdot \sin z m l)\right] \ldots \ldots
\end{aligned}
$$

但し $\quad \boldsymbol{r} / M(\rho a l) \quad($ 集中苻重と梁の重量比)

(7) 式に於て $r=0$ と置くと

$$
1-\cos m l \cdot \cosh m l=0
$$

となり，斷面一樣な兩端自由梁の振動數方程式と一致する。（7）式を滿足する $m l$ の值を求めれば，（5）より 每秒の振動數は

にて求的られる。

$$
\frac{p}{2 \pi}=\frac{(m l)^{2}}{2 \pi l^{2}} \sqrt{\frac{E I}{\rho a}}
$$

（7）式の根として， $m l$ を求めるに圖式近似法を用いた。集中荷重の位置（z）攻び重量比 $(\boldsymbol{r})$ 飞對して $(m l)^{2}$ の值を計算した結果を第 1 圖及び第 2 圖及文びA表に示す。

圖並びに表で見られる通り，集中荷重の䳩に一般に振動數は減少し，集中荷重の大きさが大になると減少量も 大となる。又集中荷重の作用位置に就いては，集中荷重の無い場合の節の附近に在る時は減少量は少く，腹の附 
近に在る場合は減少量は大となる。

本附錄の數值計算は工學士小山永敏氏（現三菱長崎造船所技師）を煩わしたものであることを附記し，著者の 感謝の意を表する次第である。

\section{VII 附錄第二 集中荷重を有する一樣な梁の實驗}

一樣な斷面を有する爾端自由梁に集中荷重 1 䇢存在する場合の振動數は，附錄第一に記載せる如く計算により 求めることが出來る。集中荷重が 2 箘以上存在する場合には Dunkerley の考方方並びにエネルギ法を䧺用して 求め得ることは，本論に於て論じた通りである。斯かる計算の信賴性に就いては Dunkerley の論文にも挨り振 動につき實驗せられている通りであるが，撓み振動に就き實驗を行つたのでその結果を头に記述せんとす。

\section{試驗梁及實驗方法}

長さ $800 \mathrm{~mm}$ 幅 $80 \mathrm{~mm}$ 厚さ約 $2 \mathrm{~mm}$ の矩形の薄鋼板を試驗梁とし， 之に重量を載貨して實驗を行つた（附 錄第 2 圖)。重量物を載貨しない場合は，兩端自由梁の節の位置をナイフ・エッデにて支えて振動せしめ，その 振動數を測る。載貨した場合は支えの位置を移動せしめて，振動數を測り，その極值を圖によつて求め（附録振 3 及び第 4 圖)，その值を所要の振動數として探用した。

實驗方法は梁の一端に於ける動きを煤紙の上に直接記錄しめ，又週期 $1 / 100$ 秒の音叉を同時に記錄せしめて第 動の週期を求めた。

試 驗 梁寸法

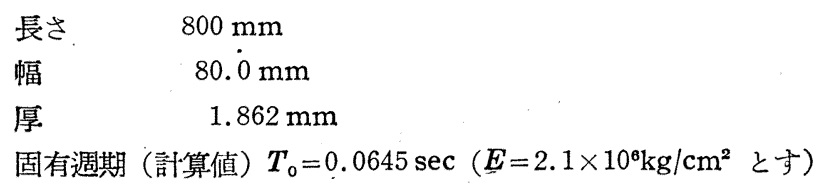

實 驗 結 果

實驗は次の種類に就き行う。

1. 中央潗中荷重 1 個を有する場合

2. 集中荷重 2 個を有する場合

3. 集中荷重 3 個を有する場合

第 1 の場合に於ては集中荷重の大きさを梁の重量 $W$ の $1 / 10,2 / 10$, 乙文び 3/10 として萓驗を行い, 第 2 の場合に於ては， $0.2 W$ の重錘を梁の中央より $80 \mathrm{~mm}$ の位置に對䊈に載貨した (附録第 2 圖參照)。 第 3 の場合は中央に $0.2 W$, 中央より各々 $80 \mathrm{~mm}$ 欢び $160 \mathrm{~mm}$ の位置に $0.1 W$ の載貨をした場合を實驗 した (附錄第 2 圖參照)。

佾載貨に用いた重鍾は長さ約 $80 \mathrm{~mm}$ 幅約 $20 \mathrm{~mm}$ の鉛板を用いた。

\section{1. 中央に集中荷重 1 箅を有する場合}

\begin{tabular}{|c|c|c|c|c|c|}
\hline \multicolumn{2}{|c|}{$0.1 W$} & \multicolumn{2}{|c|}{$0.2 W$} & \multicolumn{2}{|c|}{$0.3 \mathrm{~W}$} \\
\hline スパン & $T$ & スパン & $T$ & スパン & $T$ \\
\hline $500^{\mathrm{mm}}$ & $0.0753^{\text {sec }}$ & $480^{\mathbf{m m}}$ & $0.0789^{\text {sec }}$ & $460^{\mathrm{mm}}$ & $0.0814^{\mathrm{sec}}$ \\
\hline 440 & 0.0696 & 440 & 0.0744 & 420. & 0.0771 \\
\hline 400 & 0.0690 & 400 & 0.0725 & 400 & 0.0755 \\
\hline 350 & 0.0718 & 360 & 0.0733 & 380 & 0.0754 \\
\hline 300 & 0.0771 & 320 & 0.0762 & 340 & 0.0765 \\
\hline & & 300 & 0.0782 & & \\
\hline 極值 410 & 0.0688 & 397 & 0.0724 & 373 & 0.0756 \\
\hline
\end{tabular}




\begin{tabular}{|c|c|c|c|c|c|}
\hline \multirow{2}{*}{ 載貨重量 } & \multirow{2}{*}{ 週 期測定值 } & \multicolumn{4}{|c|}{ 比 $T / T_{\mathrm{o}}$} \\
\hline & & 測 & 定 做 & 計 & 算 值 \\
\hline 0 & $0.0646_{\text {sec }}^{\text {sec }}$ & & 1.000 & & 1.000 \\
\hline $0.1 W$ & 0.0688 & & 1.064 & & 1.065 \\
\hline $0.2 W$ & $0.07 \overline{24}$ & & 1.120 & & 1.118 \\
\hline $0.3 W$ & 0.0756 & & 1.170 & & 1.160 \\
\hline
\end{tabular}

以上の結果に示す如く集中荷重 1 籄の場合は, 計算值と實驗值は良く一致している。

\section{II. 集中荷重 2 䈏を有する場合}

測定值

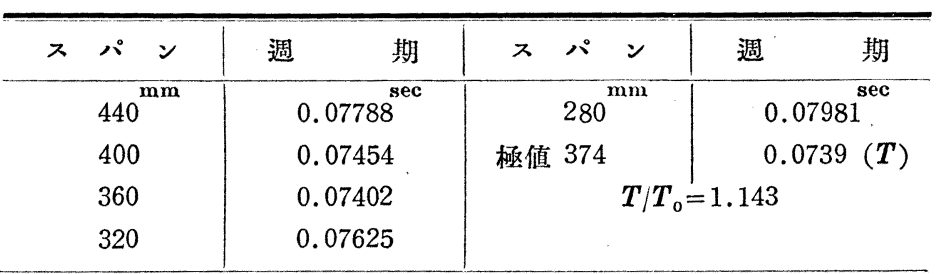

計算值

\begin{tabular}{c|c|c|c|c|c|c}
\hline 位 置 & $W . g r$. & $r$ & $z$ & $(m l)^{2}$ & $\left(u / u_{0}\right)^{2}$ & $4 r\left(u / u_{0}\right)^{2}$ \\
\hline 右 $80 \mathrm{~mm}$ & 181.9 & 0.200 & 0.1 & 20.566 & 0.268 & 0.214 \\
左 $80 \mathrm{~mm}$ & 181.8 & 0.200 & 0.1. & 20.566 & 0.268 & 0.214 \\
& & & & & & $\sum 0.428$ \\
\hline
\end{tabular}

第一法

$$
\begin{aligned}
T / T_{0} & =\left[\sum \frac{(m l)_{0}^{4}}{(m l)_{i}^{4}}-(k-1)\right]^{\frac{1}{2}} \\
& =\left[\left(\frac{22.373}{20.566}\right)^{2} \times 2-1\right]^{\frac{1}{2}}=1.170
\end{aligned}
$$

第二法

$$
T / T_{0}=\sqrt{1+0.428}=1.195
$$

\section{III. 集中荷重 3 箅を有する場合}

\begin{tabular}{|c|c|c|c|c|c|}
\hline ス & パ ン & 週 & $x$ & パ & 週 \\
\hline & $420^{\mathrm{mm}}$ & $0.07800^{\text {sec }}$ & & $300^{\mathrm{mm}}$ & $0.08144^{\text {sec }}$ \\
\hline & 380 & 0.07558 & 極值 & 373 & 0.0755 \\
\hline & 340 & 0.07623 & \multicolumn{3}{|c|}{$T / T_{0}=1.168$} \\
\hline
\end{tabular}

a) 兩側重量中央より $80 \mathrm{~mm}$ の場合 測定值

計算値

\begin{tabular}{cc|c|c|c|c|c|c}
\hline 位 & 置 & $W g r$ & $r$ & $z$ & $(m l)^{2}$ & $\left(u / u_{0}\right)^{2}$ & $4 r\left(u / u_{b}\right)^{2}$ \\
\hline 右 & 80 & 91.0 & 0.10 & 0.1 & 21.326 & 0.268 & 0.107 \\
中 & 央 & 181.7 & 0.20 & 0. & 20.017 & 0.370 & 0.296 \\
左 & 80 & 91.0 & 0.10 & 0.1 & 21.326 & 0.268 & 0.107 \\
& & & & & & $\sum 0.510$ \\
\hline
\end{tabular}


第一法

$$
T / T_{0}=\left[2 \times\left(\frac{22.373}{21.326}\right)^{2}+\left(\frac{22.373}{20.017}\right)-2\right]^{\frac{1}{2}}=1.203
$$

第二法

$$
T / T_{0}=\sqrt{1+0.510}=1.229
$$

b) 兩側重量中央より $160 \mathrm{~mm}$ の場合

\begin{tabular}{|c|c|c|c|c|c|c|}
\hline z & パ ン & 週 & ス & パ & ン & 週 \\
\hline & $440^{\mathrm{mm}}$ & $0.07592^{\text {sec }}$ & & $320^{n}$ & & $0.07570^{\text {sec }}$ \\
\hline & 400 & 0.07305 & 極值 & 382 & & 0.0729 \\
\hline & 360 & 0.07330 & \multicolumn{4}{|c|}{$T / T_{0}=1.127$} \\
\hline
\end{tabular}

測定值

\begin{tabular}{|c|c|c|c|c|c|c|}
\hline 位 置 & $W \mathrm{gr}$ & $r$ & $z$ & $(\overline{m l})^{2}$ & $\left(u / u_{0}\right)^{2}$ & $4 r\left(u / u_{0}\right)^{2}$ \\
\hline 右 $160^{\mathrm{mm}}$ & 91.0 & 0.10 & 0.2 & 22.090 & 0.075 & 0.030 \\
\hline 中 央 & 181.7 & 0.20 & 0. & 20.017 & 0.370 & 0.296 \\
\hline 左 160 & 91.0 & 0.10 & 0.2 & 22.090 & 0.075 & $\begin{array}{r}0.030 \\
\sum 0.356\end{array}$ \\
\hline
\end{tabular}

訫算值

第一法

第二法

$$
\left.T / T_{0}={ }^{r}\left(\frac{22.373}{22.090}\right)^{2} \times 2+\left(\frac{22.373}{20.017}\right)^{2}-2\right]^{\frac{1}{2}}=1.140
$$

$$
T / T_{0}=\sqrt{1+0.356}=1.163
$$

\begin{tabular}{|c|c|c|c|c|c|c|}
\hline \multirow{2}{*}{ 集中荷重數 } & \multirow{2}{*}{ 遇期測定值 } & \multicolumn{5}{|c|}{$T / T_{\mathrm{o}}$} \\
\hline & & 測 & 定 值 & 第 & 一 法 & 第 二 法 \\
\hline 2 & $0.0739^{\text {sec }}$ & & 1.143 & & 1.170 & 1.195 \\
\hline $3(a)$ & 0.0755 & & 1.168 & & 1.203 & 1.229 \\
\hline $3(b)$ & 0.0729 & & 1.127 & & 1.140 & 1.163 \\
\hline
\end{tabular}

以上集中荷重 2 箇以上存在する場合を要約すると次表の如く實驗値に比し, 第一法は 1 3\%, 第二法は 3〜 5, $\%$ 高い値を示した。

結局集中荷重の 2 䈏以上存在する場合の振動數は本法によつて數\%以下の誤差で求め得る事が實證せられた。

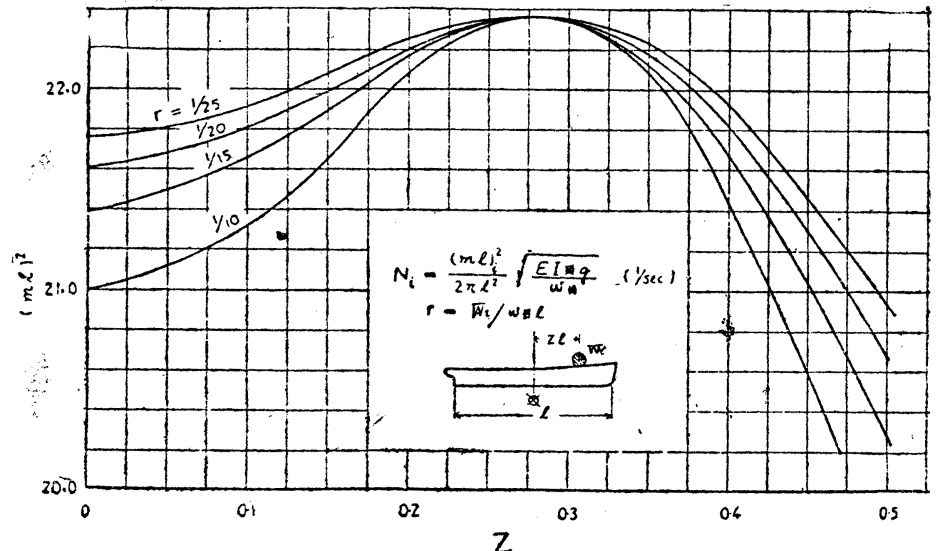

第 1 圖 集中荷重の位置に對する $(m l)^{2}$ の值 


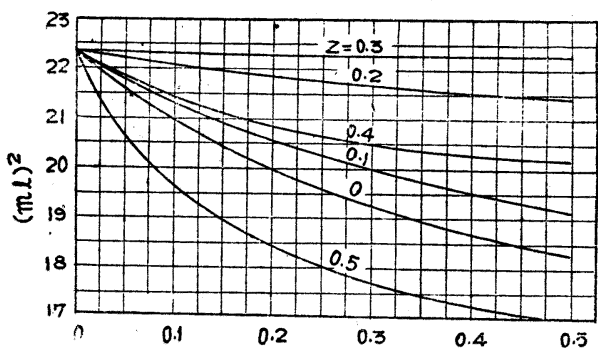

第 2 圖 集中荷重の大きさに對する $(m l)^{2}$ の值

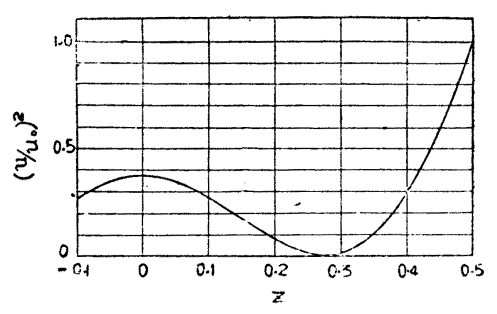

第3 圖 $\left(u / u_{0}\right)^{2}$ の值

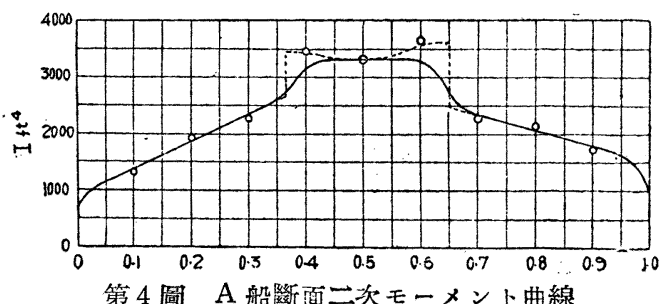

第 4 圖 A 船眑面二次モーメント曲線
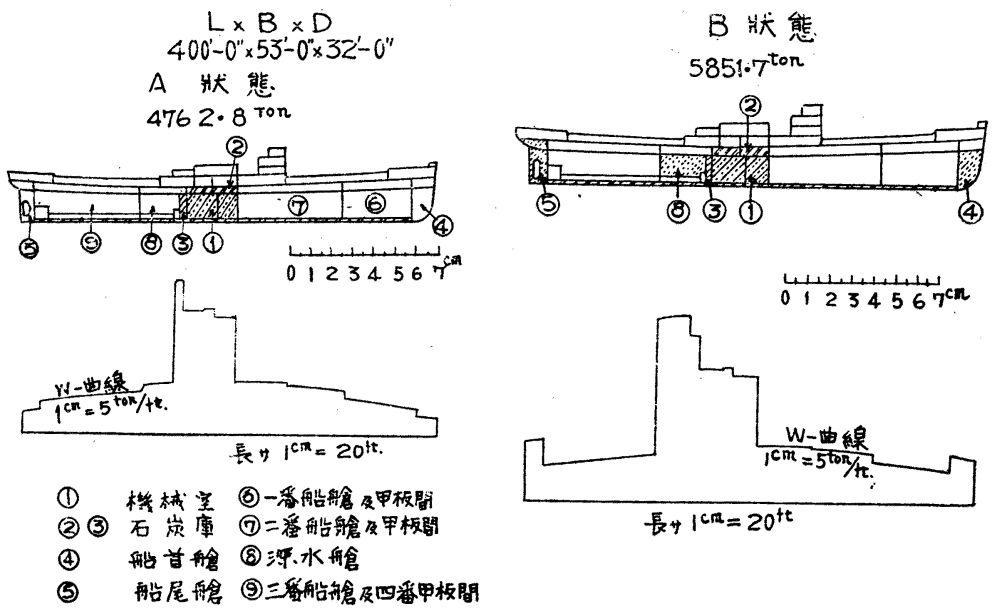

第 5 圖の 1 A 船 載貨爿態圖

第 5 圖の 2 B 狀態

C 社態.

$9406 \cdot 3^{\text {tol1 }}$

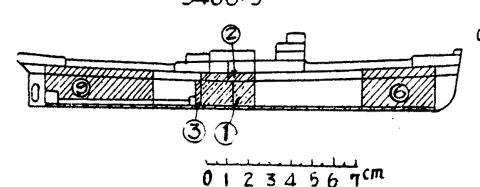

D 狀態

$9607.2^{\text {ton }}$

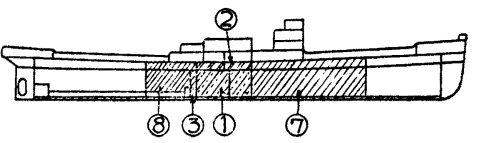

$01234567 \mathrm{~cm}$

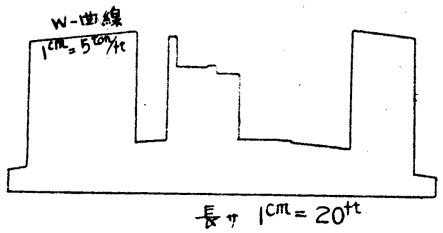

$01234567 \mathrm{~cm}$

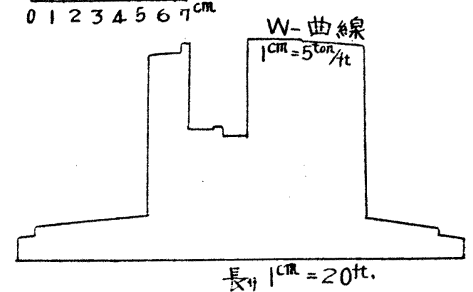

第 5 圖の 3 C 爿態

第 5 圖の 4 D 狀態 


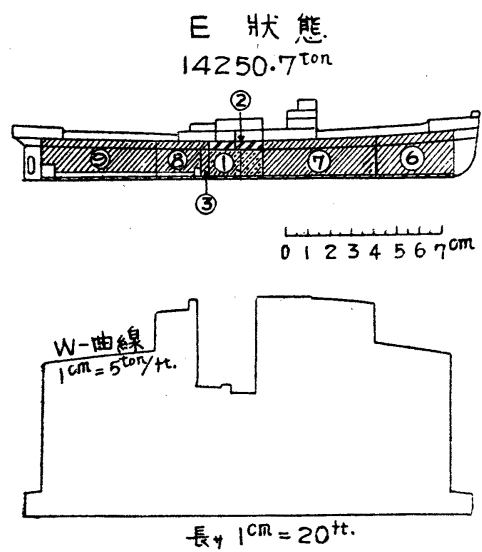

第 5 圖の $5 \mathrm{E}$ 狀態

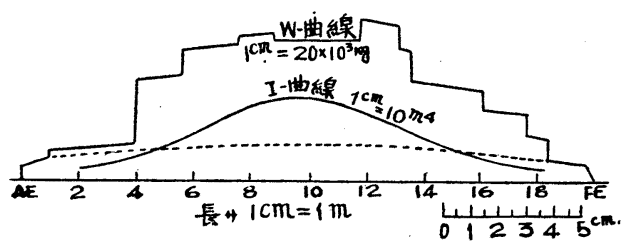

第 7 圖 C 船重量及眑面二次モーメント曲線

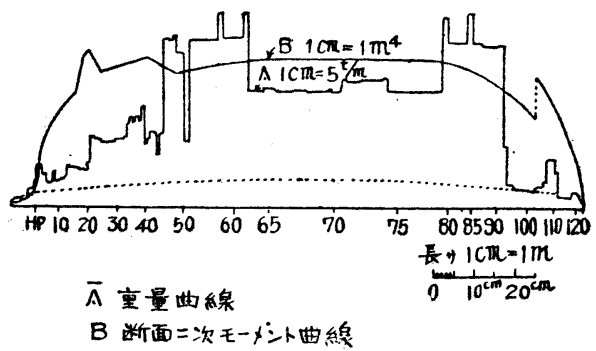

第 6 圖. B 船重量及断面二次モーメント曲線

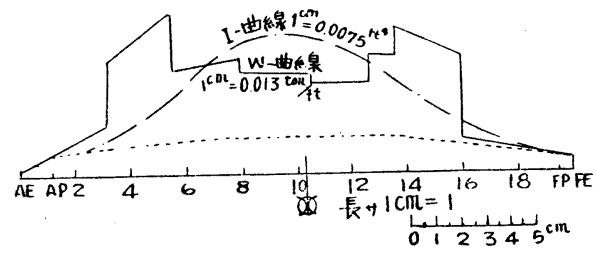

第 8 圖 D 船重量及斷面二次モーメント曲線

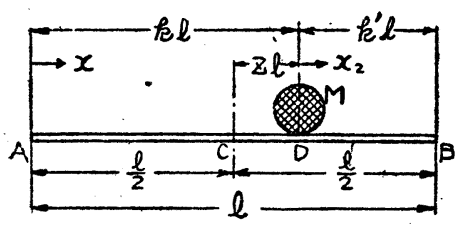

附錄 第 1 圖

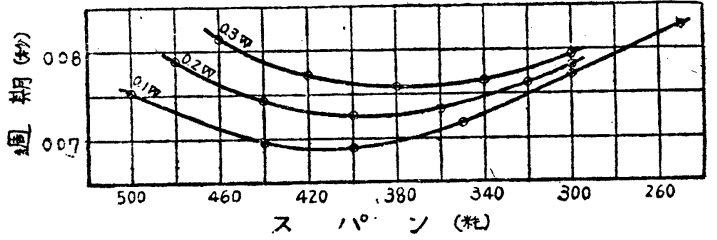

附錄 第 3 圆

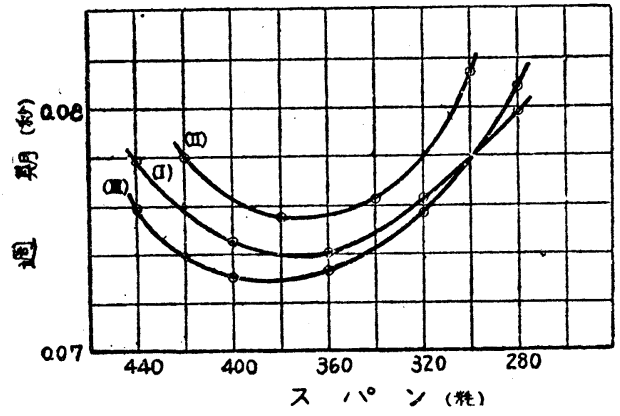

附錄 第 4 圖 
第 1 表

\begin{tabular}{|c|c|c|c|c|c|c|c|}
\hline 項 & 目 & \multirow{2}{*}{$\frac{W_{i} \text { ton }}{826.2}$} & \multirow{2}{*}{$\frac{r_{i}}{0.186}$} & \multirow{2}{*}{$\frac{z}{0.03_{5}}$} & \multirow{2}{*}{$\frac{(m l)_{i}^{2}}{20.15}$} & \multirow{2}{*}{$\frac{\left(u_{i} / u_{0}\right)^{2}}{0.358}$} & \multirow{2}{*}{$\frac{\mid 4 r_{i}\left(u_{i} / u_{0}\right)^{2}}{0.266}$} \\
\hline 機 關 & 及 燃 料 & & & & & & \\
\hline 船首 & 水 艙 & 114.3 & 0.025 & 0.46 & 21.6 & 0.665 & 0.068 \\
\hline 船尾 & 水 & 126.0 & 0.028 & $0.47_{5}$ & $21.4_{6}$ & 0.780 & 0.086 \\
\hline 樑 & 水 艙 & 848.5 & 0.191 & 0.17 & $21.4_{6}$ & 0.135 & 0.103 \\
\hline 一番 艙 & 及甲板閒 & 1955.5 & 0.440 & 0.36 & 21.2 & 0.130 & 0.229 \\
\hline 二番 艙 & 及甲板 閒 & 3764.0 & 0.845 & $0.14_{5}$ & 19.6 & 0.182 & 0.615 \\
\hline 深 水艙 & に貨物積載 & 1080.4 & 0,242 & $0.15_{\sigma}$ & $21.0_{5}$ & 0.160 & 0.155 \\
\hline 三番艙 & 及四番甲板閒. & 2687.9 & 0.602 & 0.32 & 21.9 & 0.033 & 0.080 \\
\hline
\end{tabular}

第 2 表

\begin{tabular}{c|l|l|l}
\hline 載貨狀態 & 第一法 & 第二法 & Tobin 法 \\
\hline A & $166^{1 / \text { min }}$ & 170 1/min & $165.71 /$ min \\
B & 151 & 148 & 146.0 \\
C & $155(145)$ & $146(135)$ & 127.5 \\
C & $143(136)$ & $128(129)$ & 125.6 \\
E & $136(125)$ & $119(114)$ & 106.2 \\
\hline
\end{tabular}

第 3 表

\begin{tabular}{c|c|c|c|c|c|c}
\hline 荷 重 位 置 & $W_{i} t$ & $r_{i}$ & $z$ & $(m l)^{2}{ }_{i}$ & $\left(u_{i} / u_{0}\right)^{2}$ & $4 r_{i}\left(u_{i} / u_{0}\right)^{2}$ \\
\hline F. $0-21$ & 283 & 0.056 & 0.41 & 21.65 & 9.345 & 0.077 \\
F. $21-40$ & 895 & 0.179 & 0.31 & 22.22 & 0.020 & 0.014 \\
F. $40-46$ & 257 & 0.051 & $0.25_{5}$ & 22.34 & 0.010 & 0.002 \\
F. $46-51$ & 910 & 0.182 & 0.22 & 22.05 & 0.043 & 0.031 \\
F. $51-63$ & 2560 & 0.513 & $0.13_{5}$ & 19.75 & 0.205 & 0.421 \\
F. $63-71$ & 2520 & 0.503 & 0.01 & 18.25 & 0.370 & 0.745 \\
F. $71-74$ & 1330 & 0.266 & 0.12 & 20.45 & 0.232 & 0.247 \\
F. 74-79 & 1500 & 0.300 & 0.21 & 21.70 & 0.060 & 0.072 \\
F. 79-91 & 2640 & 0.529 & 0.30 & 22.25 & 0.010 & 0.021 \\
F. $99-101$ & 102 & 0.020 & 0.44 & 21.82 & 0.520 & 0.041 \\
\hline
\end{tabular}

第 4 表

\begin{tabular}{c|c|c|c|c|c|c|c}
\hline \hline 重 量 位 置 & $W_{\mathrm{t} n \mathrm{n}}$ & $\boldsymbol{r}$ & $z$ & $(m l)^{2}$ & $\left(u / u_{\mathrm{o}}\right)^{2}$ & $4 r\left(u / u_{\mathrm{o}}\right)^{2}$ \\
\hline $0-1$ & 66 & 0.012 & $20.4_{\text {s }}$ & 22.16 & 0.430 & 0.021 \\
$1-2$ & 130 & 0.024 & 0.35 & 22.26 & 0.100 & 0.010 \\
$2-3$ & 800 & 0.149 & 0.26 & 22.30 & 0.004 & 0.002 \\
$3-4$ & 1440 & 0.268 & 0.16 & 21.05 & 0.155 & 0.166 \\
$4-4.5$ & 1030 & 0.192 & 0.09 & 20.55 & 0.285 & 0.219 \\
$4.5-6$ & 2300 & 0.427 & 0.01 & 18.57 & 0.368 & 0.629 \\
$6-7$ & 1480 & 0.275 & $0.12_{\text {s }}$ & 20.45 & 0.223 & 0.245 \\
$7-8$ & 1170 & 0.218 & 0.25 & 22.20 & 0.008 & 0.014 \\
$8-9$ & 500 & 0.093 & $0.34_{\text {v }}$ & 22.05 & 0.085 & 0.031 \\
$9-10$ & 110 & 0.021 & 0.40 & 22.10 & 0.290 & 0.024 \\
\hline
\end{tabular}


第 5 表

\begin{tabular}{c|c|c|c|c|c|c}
\hline 重 量 位 置 & $W_{\mathbf{t ~ n}}$ & $\boldsymbol{r}$ & $z$ & $(m l)^{2}$ & $\left(u / u_{0}\right)^{2}$ & $4 \boldsymbol{r}\left(u_{i} / u_{0}\right)^{2}$ \\
\hline A P - 3 & 0.015 & 0.037 & 0.375 & 22.13 & 0.185 & 0.027 \\
$3-5.5$ & 0.147 & 0.358 & 0.275 & 22.20 & 0.002 & 0.003 \\
$5.5-8$ & 0.099 & 0.242 & 0.160 & 21.10 & 0.115 & 0.150 \\
$8-10.5$ & 0.088 & 0.214 & 0.040 & 20.00 & 0.350 & 0.300 \\
$10.5-12.5$ & 0.064 & 0.156 & 0.080 & 20.73 & 0.305 & 0.190 \\
$12.5-13.5$ & 0.042 & 0.102 & 0.155 & 21.60 & 0.165 & 0.067 \\
$13.5-16$ & 0.085 & 0.208 & 0.235 & 22.10 & 0.025 & 0.021 \\
\hline
\end{tabular}

附錄 A表 $(m l)^{2}$ の 值

\begin{tabular}{l|l|l|c|c|c|c}
\hline \multicolumn{1}{c|}{$\boldsymbol{z}$} & \multicolumn{1}{c|}{0} & 0.1 & 0.2 & 0.3 & 0.4 & 0.5 \\
\hline 0 & 22.373 & 22.373 & 22.373 & 22.373 & 22.373 & 22.373 \\
0.05 & 21.61 & 21.81 & 22.222 & 22.345 & 21.818 & 20.666 \\
0.1 & 20.995 & 21.325 & 22.090 & 22.343 & 21.428 & 19.634 \\
0.2 & 20.02 & 20.566 & 21.856 & 22.326 & 20.867 & 18.447 \\
0.3 & 19.28 & 20.017 & 21.669 & 22.307 & 20.521 & 17.741 \\
0.4 & 18.705 & 19.528 & 21.530 & 22.288 & 20.304 & 17.289 \\
0.5 & 18.275 & 19.141 & 21.391 & 22.269 & 20.160 & 16.941 \\
\hline
\end{tabular}

討 論

○寺澤一雄君 私今やつて見をのですが，非常に長いるのを一つの所に集中する代りに，思い切つて全體を異中 にもつて來をら何らかと思います。案外上くあうんです。全體のLoad を $n$ を今の方法で補正すると，Aの

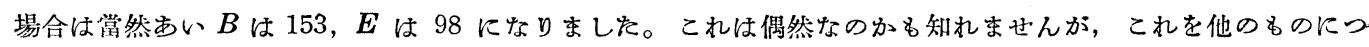
いて試みて下さつをらどんなものでしょら。

○吉識雅夫君 $A$ 船の狀㿟でもるら一つ宛きつて集中荷重の數を多くしてゃると，第一の方法でるるら少し Tobin 法の值に近くなつて出ます。D では 136 と云ら風にTobin に近くなります。から云えるか何らか分り ませんが第一の方法は多少銳敏热感じがします。今の和話の㥞に全體を一つの集中荷重に置きかえると云うこ そは考元ませんでしね。

○寺澤一雄君 粗つぼすると云らのは, 船の樽なものを一本の棒でやつても案外違はないといら考をどこまで むやると云ら事です。

O吉識雅夫君 御承知の通り Tobin は $I$ \& $w$ る本均値を取り，それに補正しています。それが和話の方法と ぞら云ら關保にあるか分りませんが可成り良く一致することは面白いと思います。私の考穴にのは出來るだけ 設計の初期に得られると云らことが主眼目で多少歒暴です止むを得ないと思つてやつたのですが，和說の方法 は研労を要するものと思います。 
○渡邊惠弘君 船體の彈性保數 $E$ の值はどらゃつて出されましたか。

○吉識雅夫君 計算しててのは材料の $E$ の值をとりましま。

O渡尰惠弘君 $I$ は

○吉識雅夫君 $I$ \&見掛の值をその儘取りました。

○渡隩惠弘君 水に浮んでいる時の水のinertiaの問題とかの補正の問題には今度は全然觸れて居ないのですか。

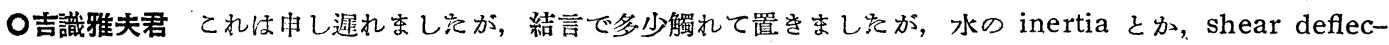
tion 等の如き補正の問題が澤山有りますが，現在の處觸れていません。D船の值の違いはそれによるのでは ないかと思います。 shear deflection. 水の effect 等を入れて計算する方法は發表されていますがてれるは 後で入れるとして先ず其の基礎となるるのを求める目的のるのです。

○渡邊惠弘君 荷物を積んだ時は振動に對する質量增加の問題は單に荷重の $w$ によるののみならず，吃水の

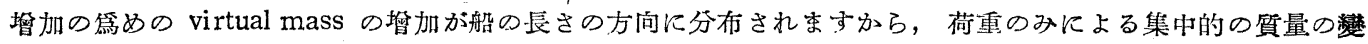
化丈けを考ええのではいけないと思います。

（追記一著者の方法に依つて，載貨の篇めの振動數の變化を求むる場合は， virtual mass の變化の影響が入 つて來て, 却々難かしくなると思いますが，一般に實船の $E I$ 及質量（virtual mass を含んだ）の分布は非 常に不規則で，その山 $E I$ の不規則性の影響は小さく Todd Burrill も云つて.居る樣に大體船の中央 $3 / 5 L$ の閒の值できまる故，船體中央部の $E I$ 值を取つても大しを誤りはなく，結局質量の分布狀態の影響が重要 となります。故に之を本均一樣分布と, 更に不規則な(十)及(一)の分布との和と考完, 此不規則分布を幾つかの interval に別つて, 之に著者の方法を適用すれば, 振動數は今迄のゃり方よりる簡單に求まり, 此栐なゃり方 が此論文の目的と解すれば非常に興味深く, 有晙なものと思いすす。一言附け加之すす)

○吉識雅夫君 Taylor の言つていますのは, 大體 virtual mass が吃水に逆比例する樣に表わして居り，B/2d で加わる形で表わしていたかと思いますが，今の扣話の棣に吃水が變ると virtual mass も變り且その分布狀 態も變化し夫が振動數に關係することは當然と思います。

○井上隆介君 一つ教えて頂きたいのですが，筫船の自己振動數はどらゃつて測るのでしよらか。

○吉識雅夫君 $C$ 船の測つたのは文獻から取つて來をので, ぞらゃつて測つをか詳しい事は分りません。

○并上隆介君 Tobin の方法に比べて居られますが，これが一番實際の値に近いからですか。

○吉識雅夫君 Tobinの方法が一番良いと云ら意味ではありません。諸種の補正をしない方法では結局求めを值 がいつも筫際の值と違つて何十パーセントがきく出てきます。實測しそ值との差は virtual mass とか, shear deflection の問題になると思います。先程渡邊博士の扣話もありましを通り virtual mass 並にその 分布等が閒題になりますが，夫等の補正の值を知るをめには，其の補正をしない前の振動方程式を解いた基礎 となる數字を出し，夫と蛽測值と比へて始めて夫等の補正が論じられることになります。所が振動方程式を解 く事は可成り面倒な仩事で造船所で常にゃって頂りるとは限りません。夫で簡單で且設計初期に得られる樣な 伍かな資料で計算が出來て, 夫が例えばTobin 法で得られる值に近い值が求められることになれば, 造船所等 でいつもこの計算を實行し實测しを值と比較するこがと出來る。そうすれば virtual mass とか, shear deflection の effect その他が，ぞの船ではどの位，ぞらいら狀態では幾らと云ら結果が得られ，之等の問題の 進展を與える基となるものと考えて居る次第で，今值ちに實測値と比較する事は考えて居りません。 